\title{
VREDNOTENJE SISTEMOV JAVNEGA POTNIŠKEGA PROMETA V IZBRANIH OBČINAH SLOVENIJE
}

\author{
dr. Matej Ogrin*, Matjaž Dovečar**, univ. dipl. geogr. \\ * Oddelek za geografijo, Filozofska fakulteta Univerze v Ljubljani, \\ Aškerčeva 2, SI- 1000 Ljubljana \\ ** Lamutova 26, SI-I I 26 Ljubljana Podutik \\ e-mail: matej.ogrin@ff.uni-lj.si, matjaz.dovecar@gmail.com
}

\section{Pregledni znanstveni članek}

COBISS 1.02

DOI: $10.4312 /$ dela.42.6.115-127

\section{Izvleček}

Javni potniški promet v Sloveniji nazaduje že nekaj desetletij, spremlja pa ga močan porast motorizacije. Slovenija je doživela motorizacijo v zadnjih desetletjih še bolj izrazito kot večina drugih držav EU, kar je privedlo do netrajnostnega prometnega sistema, ki je drag in povzroča prekomerno onesnaževanje ter krni kakovost življenja v mestih. Zato je v zadnjih letih ponekod opaziti znake oživljanja praks trajnostne mobilnosti. Prispevek se posveča stanju in primerjavi javnega potniškega prometa ter ukrepom podpore mestnega potniškega prometa $\mathrm{v}$ izbranih slovenskih občinah.

Ključne besede: mobilnost, javni potniški promet, Slovenija, mestni potniški promet, vrednotenje

\section{EVALUATION OF PUBLICTRANSPORT IN SELECTED SLOVENIAN MUNICIPALITIES}

\begin{abstract}
In Slovenia public transport is in decline already for few decades. At the same time, the country faces a strong growth of motorisation. Its growth was even stronger than in most of EU countries, which resulted that Slovenian transport system is very expensive, it causes excessive air pollution and is far from sustainable. However, in some cities and areas in last years we can notice some signs of public transport recovery. The article compares public transport systems in selected Slovenian municipalities and shows which measures were taken to implement recovery of transport systems.
\end{abstract}

Key words: mobility, public transport, Slovenia, city transport, evaluation 


\section{UVOD}

Javni potniški promet je v razvitih državah pomembna alternativa osebnemu motoriziranemu (t. j. avtomobilskemu) prevozu in pomembno prispeva k socialni enakopravnosti na področju mobilnosti ter k vključevanju vseh družbenih skupin v socialne kroge. Prav tako razvit javni promet pomembno zmanjšuje gnečo na mestnih cestah, povečuje energetsko in stroškovno učinkovitost prometnega sistema, povečuje prometno varnost ter zmanjšuje onesnaževanje ozračja, obremenjevanje okolja s hrupom in izpuste toplogrednih plinov. Zmanjšuje tudi mobilnostni razkorak in je pomemben del trajnostne mobilnosti, ki jo v številnih mestih ponovno poskušajo vpeljati, potem ko so se v preteklih desetletjih intenzivne motorizacije deleži javnega potniškega prometa $\mathrm{v}$ večjih mestih zmanjševali in so številna mesta preplavili avtomobili. »Učinkovit javni potniški promet lahko v kratkem času in z nizkimi stroški prepelje veliko število potnikov. Omogoča kakovostno dostopnost do glavnih ciljev za vse skupine prebivalcev, zmanjšuje s prometom povezane težave ter izboljšuje delovanje naselij.«(Ogrin in sod., 2013, str. 8).

Slovenija je na področju javnega potniškega prometa v zadnjih 30 letih doživela velike spremembe, žal na slabše, kar nam potrjujejo mnogi kazalci. Hitra rast motorizacije je močno spremenila način življenja, omogočila hitrejšo in več mobilnosti, hkrati pa prinesla tudi številne negativne učinke. Danes Slovenci sodimo med najbolj motorizirane narode v Evropi, saj kar 86 \% kopnih poti opravimo z avtomobilom, kar nas uvršča na tretje mesto v EU (EU transport in figures 2014, 2014).

Kako korenite spremembe je doživela slovenska družba, nam pove tudi podatek o rasti motorizacije: še leta 1955 sta bili v Sloveniji na 1000 prebivalcev le dve osebni vozili, leta 1980 smo dosegli 218 vozil na 1000 prebivalcev, leta 2012 pa kar 518 osebnih vozil na 1000 prebivalcev, medtem ko je povprečna motorizacija v EU to leto znašala 487 osebnih vozil na 1000 prebivalcev (Lampič, Ogrin, 2009; EU transport in figures 2014, 2014). Leta 2012 smo v motorizaciji dosegli deveto mesto v EU, v povprečju pa je slovenska družina za mobilnost porabila 16,1 \% družinskega prihodka in le dve državi EU sta porabili večji delež od Slovenije (EU transport in figures 2014, 2014).

Hkrati z rastjo motorizacije je Slovenija doživela izrazit upad povpraševanja v javnem potniškem prometu. Odstotek zaposlenih, ki se na delo vozijo z javnim potniškim prometom, je leta 1981 znašal $64 \%$, leta 2001 pa le še $10 \%$ (Bole, Gabrovec, 2012). Ti trendi se negativno kažejo tudi pri okoljskih kazalcih. Samo od leta 1986 do leta 2010 so izpusti toplogrednih plinov iz prometa narasli za $258 \%$ (Mekinda, Česen, 2012), promet pa je v istem letu prispeval $27 \%$ vseh izpustov toplogrednih plinov v Sloveniji in je za energetiko drugi sektor po deležu izpustov (Greenhouse gas emission trends ..., 2012). V EU je bilo leta 2009 47,5 \% izpustov dušikovih oksidov posledica prometa (Sector share of ..., 2012). V Sloveniji je ta delež leta 2007 znašal 56 \%, medtem ko je cestni promet v Sloveniji istega leta povzročil 42 \% izpustov dušikovih oksidov (Rode, 2009), leta 2011 pa 54 \% (Kakovost zraka v Sloveniji v letu 2012, 2013). V večjih mestih lokalno že prihaja do prekomernega onesnaženja zraka, ki ga povzročajo tokovi dnevnih migracij (Ogrin in sod., 2006; Ogrin, 2008; Ogrin, Vintar Mally, 2013; Ogrin in sod., 2014). 
Pomemben dejavnik krepitve motorizacije je tudi prostorski razvoj Slovenije, zaradi katerega se krepi poselitev vzdolž pred kratkim zgrajenega avtocestnega križa, ki je močno skrajšal potovalne čase do večjih središč ob avtocestnem križu (Celje, Maribor, Kranj, Jesenice, Koper, Izola, Novo mesto, Nova Gorica, Murska Sobota, Ptuj), zlasti pa do Ljubljane. Bole in Gabrovec (2012) sta dokazala povečano število dnevnih potovanj vzdolž avtocestnega križa v obdobju 2000-2009, zlasti na relacijah med Mariborom, Celjem in Ljubljano, Ljubljano in Koprom, Ljubljano in Jesenicami, iz Notranjske in Dolenjske v Ljubljano ter znotraj Ljubljanske urbane regije. Kot ugotavlja Kozina (2010), predstavlja prometna dostopnost pomemben dejavnik razvoja poselitve v Sloveniji, kar posledično krepi poselitev vzdolž avtocestnega križa. Vendar pa neuravnotežen prometni razvoj, ko javni potniški promet stagnira ali nazaduje, hkrati pa hitro raste stopnja motorizacije, povečuje tudi visoke stroške prometnega sistema, s sistemom povračil potnih stroškov zaposlenim v obliki finančnega nadomestila pa ustvarja začarani krog, ko se denar vedno znova preusmerja $\mathrm{v}$ osebni promet, namesto $\mathrm{v}$ javni potniški promet.

Prav veliko sodobnih študij o javnem potniškem prometu v Sloveniji ne premoremo, manjka tudi celovit pregled sistemov javnega potniškega prometa v Sloveniji. Vseeno se pojavljajo nekatere raziskave, ki kažejo določeno stopnjo zanimanja za to problematiko in morda nakazujejo povečano zanimanje ne le stroke, pač pa tudi politike in investitorjev za to področje. Jezeršek (2012) je raziskovala stanje mestnega javnega potniškega prometa v mestni občini Koper in v občini Piran. Ugotavlja, da je v mestni občini Koper gostota avtobusnih prog dobra, $94 \%$ prebivalstva ima postajališče oddaljeno manj kot $250 \mathrm{~m}$ od bivališča, tudi pogostnost voženj je dobra. V celoti gledano je organizacija javnega potniškega prometa dobra, njegova uporaba pa narašča. V občini Piran je pokritost znotraj 250-metrskega pasu od postajališča 71-odstotna, za obe občini pa avtorica sklene, da je uporaba javnega potniškega prometa še vedno premajhna ter da ta potrebuje izboljšanje kakovosti storitev (Jezeršek, 2012, str. 289).

Da je kakovost storitev potniškega prometa pomembnejša od cene, ugotavlja Jemenšek (2010) na primeru modela vzpostavitve trajnostnega potniškega prometa $\mathrm{v}$ občini Škofja Loka. Linijske prevoze nadgrajuje storitev javnih prevozov na poziv, ki pa je namenjena predvsem starejšim in gibalno oviranim osebam. Zelo pomembna je tudi skrb za promocijo javnega potniškega prometa in komuniciranje $\mathrm{z}$ uporabniki ter spremljanje ukrepov in njihovih učinkov (Jemenšek, 2010, str. 287). Omeniti velja tudi magistrsko delo z naslovom Javni potniški promet na ruralnih območjih Republike Slovenije v funkciji zadovoljevanja javnih potreb (Zupančič, 2007). Avtor je na primeru občine Komen ugotovil, da za zagotavljanje minimalne mobilnosti prebivalstva v ruralnih območjih ni nujno potrebno vpeljati javnega potniškega prometa, pač pa se lahko vpelje nekatere inovativnejše oblike prometa, ki so v tujini v uporabi že vrsto let. Sem sodijo npr. integracija šolskega in rednega prevoza - lahko tudi z manjšimi vozili, subvencionirani prevozi na klic, model prostovoljnih prevozov, model kombiniranega prevoza potnikov in blaga ali model deljenega lastništva vozil (Zupančič, 2007, str. 173-174).

Zaradi dolgoletnega zapostavljanja postaja vlaganje v sistem javnega potniškega prometa vse večja nuja, kajti posledice hitre motorizacije poleg omenjenih težav povzročajo tudi že dnevne zastoje na vpadnicah in obvoznicah, kar je jasen znak preobremenjenosti 
cestne infrastrukture. Velik del dnevnih migracij lahko prevzame ravno javni potniški promet, če je organiziran kakovostno. Da bi dobili podrobnejši in bolj celovit vpogled v stanje mestnega potniškega prometa, smo se lotili raziskave o ukrepih na področju javnega potniškega prometa v izbranih slovenskih občinah, kjer je tovrstni promet organiziran. Ukrepi kažejo odnos občin do tega segmenta mobilnosti, kažejo tudi zavedanje o pomembnosti javnega potniškega prometa $\mathrm{v}$ občinah in njihovo pripravljenost, da trende stagnacije in nazadovanja postopno ustavijo ter obrnejo navzgor. Raziskava je pokazala tudi stanje na določenih segmentih javnega potniškega prometa v izbranih občinah, kot tudi na določene metodološke težave, ki jih bo potrebno odpraviti pri ponovitvi raziskave v naslednjih letih.

\section{METODE DELA}

Osredotočili smo se na enajst mestnih občin (Ljubljana, Maribor, Kranj, Koper, Celje, Novo mesto, Velenje, Nova Gorica, Ptuj, Murska Sobota in Slovenj Gradec) in šest občin, v katerih imajo organiziran mestni potniški promet, pri čemer ni bilo nujno, da se potniški promet formalno imenuje mestni, le da ima vlogo mestnega prometa (Krško, Škofja Loka, Jesenice, Piran, Postojna in Idrija). Poleg teh smo v raziskavo vključili tudi občini Kamnik in Brežice, ker je občina Kamnik uvedbo javnega potniškega prometa že načrtovala, občina Brežice pa ima vzpostavljen učinkovit sistem medkrajevnega potniškega prometa.

Slika 1: Občine z organiziranim mestnim prometom v letu 2011

Figure 1: Municipalities with organised public transport

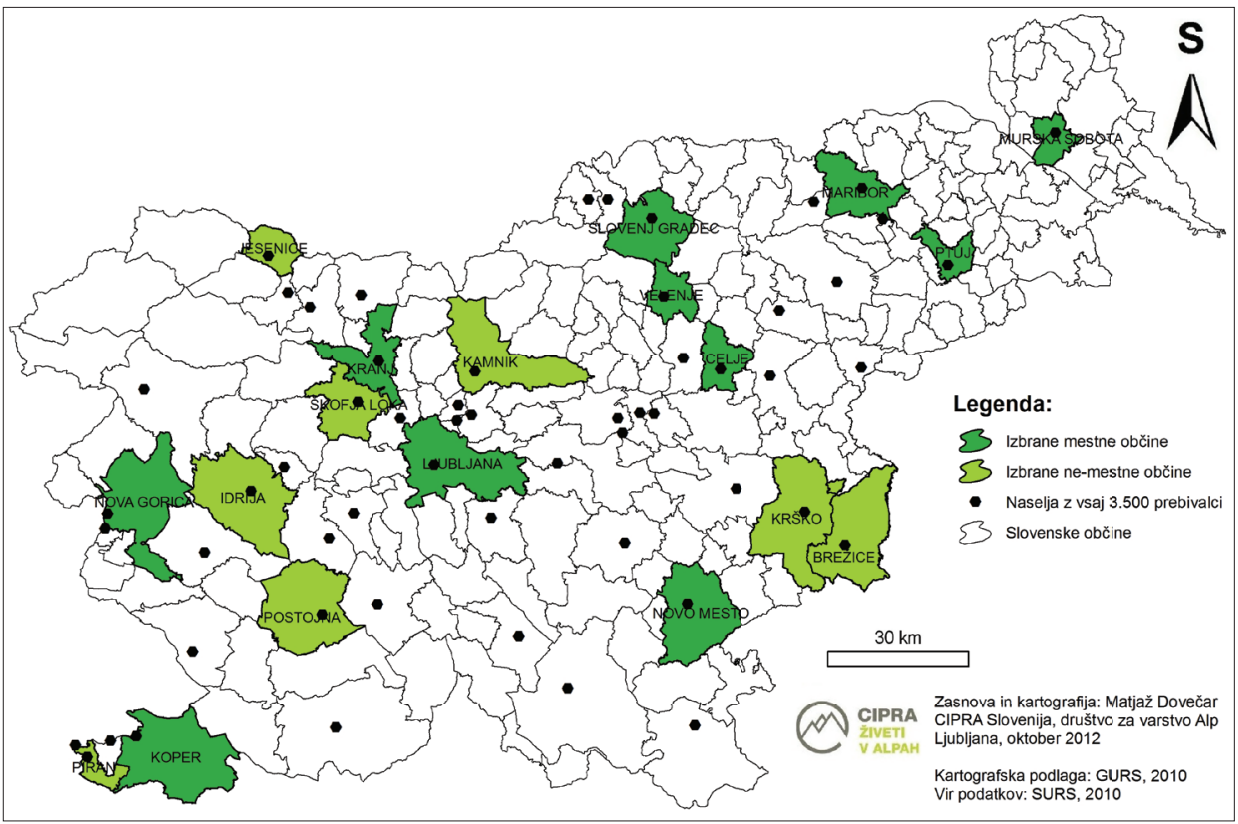


Pri nekaterih občinah velja izpostaviti določene posebnosti. Mestna občina Celje v času raziskave še ni imela organiziranega mestnega potniškega prometa, prevoze znotraj občine je opravljal primestni potniški promet. Prav tako mestni promet ni bil organiziran v mestnih občinah Ptuj in Slovenj Gradec. Raziskava je bila del projekta Integrirani javni potniški promet - izobraževanje, informiranje in ozaveščanje javnosti o pomenu javnega potniškega prometa $\mathrm{z}$ delovnim imenom Dobimo se na postaji. Naročnik je bilo Ministrstvo za infrastrukturo in prostor, financiral pa se je delno iz Kohezijskega sklada EU v okviru Operativnega programa razvoja okoljske in prometne infrastrukture za obdobje 2007-2013.

Metodologija sestoji iz dveh korakov. Sprva smo opravili temeljito zbiranje informacij na podlagi vprašalnika o javnem potniškem prometu v omenjenih občinah. Vprašalnik je vseboval devet tematskih sklopov, in sicer:

- Oblika javnega potniškega prometa;

- Mestni avtobusni promet;

- Opremljenost postajališč mestnega potniškega prometa;

- Intermodalnost javnega potniškega prometa;

- Medkrajevni avtobusni potniški promet;

- Železniški potniški promet;

- Območja za pešce;

- Medobčinsko povezovanje na področju prometa;

- Občina in trajnostna mobilnost.

Podatki, ki so jih posredovale občine, so se nanašali na stanje javnega potniškega prometa v Sloveniji v letu anketiranja (2010), nekateri pa na obdobje 2005-2010. V občinah so nam odgovarjale osebe, pristojne za prometno dejavnost, oziroma zaposleni na gospodarskem oddelku, ki opravlja tudi naloge, povezane s prometom. Izkazalo se je, da je zelo malo občin, ki imajo zaposlene prave prometne strokovnjake, pogosto niti ni bila na voljo oseba, ki bi vedela vse odgovore, ki smo jih iskali. Če določena oseba ni poznala ustreznih odgovorov ali je bilo njeno poznavanje tematike pomanjkljivo, smo jih iskali na drugih oddelkih občin. Poizvedovanje je potekalo v obliki osebnih intervjujev, izpolnjevanja po pošti, v nekaj primerih je šlo tudi za pregled dokumentacije, ki smo jo dobili na vpogled. Zbrane informacije smo preverili znotraj konzorcija partnerjev projektne skupine in po potrebi - če se je izkazalo, da so odgovori pomanjkljivi ali celo malo verjetni - izvedli ponovno povpraševanje $\mathrm{z}$ dodatnimi pojasnili. $\mathrm{V}$ posameznih primerih smo manjkajoče dopolnili s podatki Statističnega urada RS.

Na podlagi izbranih kazalcev, s katerimi smo želeli ugotoviti izboljšave in ukrepe v sistemih javnega potniškega prometa, smo želeli poleg stanja izpostaviti tudi napore, ki jih posamezne občine vlagajo na tem področju. Pri vsakem sklopu kazalcev smo določili osnovnega, ki je najpomembnejši in je pri vrednotenju prinesel največ točk, poleg tega pa smo določili še največ dva dopolnilna kazalca, ki po svojem vplivu sicer ne moreta preseči osnovnega, lahko pa podajata jasnejšo sliko. Namen vrednotenja ni bil kazati na absolutne zmagovalce ali poražence, pač pa izpostaviti razlike med občinami, identificirati tiste, kjer je nabor ukrepov največji ter pripraviti osnovo za vrednotenje v prihodnosti. 
V dosedanji fazi se je kot prva metodološka težava pokazalo subjektivno vrednotenje anketirancev pri nekaterih kazalcih, vendar smo to, kadar so se odgovori izkazali za malo verjetne, $\mathrm{v}$ veliki meri odpravili s ponovnim povpraševanjem in $\mathrm{z}$ dodatnimi pojasnili. Druga težava so bile velike razlike med občinami, tako glede velikosti kot tudi preteklega razvoja sistema javnega potniškega prometa in njegove vloge. Zaradi tega je neposredna primerljivost rezultatov lahko vprašljiva, a kot smo že napisali, tudi ni bila glavni namen raziskave.

\section{I. Kazalci za vrednotenje ukrepov na področju javnega prometa po izbranih občinah}

\section{Kazalci raznolikosti ponudbe}

Osnovni: Povezanost občine z železnico: 4 točke

Dopolnilna: Organiziranost mestnega potniškega prometa: če je organiziran, 1 točka

Druge oblike javnega potniškega prometa: vsaka oblika prinese 1 točko, največ 3 točke

Obrazložitev: Raznolikost ponudbe javnega potniškega prometa kaže na celovitost obravnavanja vloge javnega potniškega prometa s strani načrtovalcev, na možnost intermodalnosti in širše uporabe javnega potniškega prometa nasploh. Pomanjkljivost tega kazalca je, da občine v glavnem nimajo vpliva na potek železnice na svojem ozemlju, a se to vseeno odraža na njegovi kakovosti. Vendar imajo občine vpliv na organiziranost drugih oblik javnega potniškega prometa na svojem območju, zato smo ga vključili kot pomožni kazalec.

\section{Kazalca rasti ponudbe}

Trend prevoženih potnikov, izražen z verižnim indeksom: stagnacija 1 točka, rast 2 točki Spreminjanje dolžine avtobusnih prog v kilometrih: stagnacija 1 točka, rast 2 točki

Obrazložitev: Kazalca sta jasna pokazatelja razvoja javnega potniškega prometa. Dolžina avtobusnih prog kaže na vlaganje upravljavca (lahko tudi občine) v dosegljivost javnega potniškega prometa. Sprva smo v to kategorijo želeli uvrstiti tudi trend potniških kilometrov, a se je izkazalo, da občine ta kazalec merijo zelo pavšalno, izračun le-teh pa je iz danih podatkov nemogoč. Dokler vsi sistemi javnega potniškega prometa ne bodo imeli elektronskih vozovnic, podatkov o potniških kilometrih kot kazalcu za vrednotenje ne bomo mogli uporabljati.

\section{Kazalca cenovne politike}

Osnovni: Sofinanciranje javnega potniškega prometa (znesek v EUR na občana): nadpovprečna vrednost zneska prinese 3 točke

Dopolnilni: Cena vožnje je manj kot 1 EUR: če je cena nižja od 1 EUR, 1 točka

Obrazložitev: Višina sofinanciranja na občana je ključen pokazatelj vlaganja občine v zagotavljanje mobilnosti občanov. Pomanjkljivost kazalca je, da se lahko v neki občini 
zmanjšuje število prebivalcev in bo zato znesek subvencije na občana narasel ob enaki višini skupne subvencije. Cena vožnje je lahko pomemben dejavnik, ki odloča o uporabi javnega potniškega prometa - nižja cena ene vožnje spodbuja njegovo uporabo.

\section{Kazalci kakovosti voznega parka}

Osnovni: Starost voznega parka: manj kot 2 leti (3 točke), 2-5 let (2 točki), 6-10 let (1 točka), več kot 10 let (0 točk)

Dopolnilna: Delež emisijskih standardov EURO 4 in EURO 5: večji kot 75 \% (1,5 točke), 51-75\% (1 točka), 26-50\% (0,5 točke), manj kot $25 \%$ (0 točk)

Delež nizkopodnih avtobusov: večji kot $75 \%$ (1 točka), 51-74 \% (0,5 točke), manj kot $50 \%$ (0 točk)

Obrazložitev: Na kakovost voznega parka kaže več vrst podatkov. Izločili smo pomembnejše, kot so podatki o starosti voznega parka, o kakovosti emisijskih standardov motorjev vozil in o deležu nizkopodnih vozil, ki so primerna za vožnjo gibalno oviranih oseb in nasploh primernejša za vstopanje. Pomanjkljivost tako osnovnega kot dopolnilnih kazalcev je, da v mestih in občinah, kjer so sistemi javnega potniškega prometa mlajši in manjši, na lažji način dosežejo večji delež kakovostnejših vozil, kot pri mestih z večjimi sistemi javnega potniškega prometa (npr. Ljubljana in Maribor).

\section{Kazalec opremljenosti postajališč}

Delež postajališč, opremljenih z nadstreški, klopmi, voznimi redi in shemo prog: večji kot $75 \%$ (3 točke), 51-75 \% (2 točki), 26-50 \% (1 točka), manjši kot 25\% (0 točk)

Obrazložitev: Opremljenost postajališč kaže na pomemben vidik kakovosti storitve javnega potniškega prometa, saj je zelo pomembno, da so postajališča za uporabnike kar se da udobna in tudi na pogled vabljiva. Pomanjkljivost tega kazalca je, da lahko gre pri odgovorih za subjektivno oceno vprašanih, kar terja večji trud pri anketiranju in preverjanju, lahko pa je potreben tudi terenski ogled.

\section{Kazalci intermodalnosti}

Osnovni: Združenost terminalov vseh sistemov javnega potniškega prometa na enem mestu: če so združeni (3 točke)

Dopolnilni: Urejenost kolesarnice na avtobusni oziroma železniški postaji: da (1 točka) Organiziranost parkirišč po sistemu parkiraj in se pelji $(P+R)$ : da (1 točka)

Obrazložitev: Skrb za intermodalnost javnega potniškega prometa je v Sloveniji še zelo majhna in nesistematična, čeprav je intermodalnost eden ključnih pogojev za kakovosten javni potniški promet. Slabemu splošnemu stanju navkljub smo preverili razmere in s tem kazalcem opozorili na pomembnost intermodalnosti pri doseganju kakovostnega javnega potniškega prometa. Pomanjkljivost tega kazalca je, da je z vidika doseganja intermodalnosti težko ovrednotiti posamezno ponudbo, ki je nastajala nenačrtno. 


\section{Dodatna skupina kazalcev za vrednotenje načrtovalskega vidika}

Ta skupina kazalcev je le informativnega značaja in je nismo točkovali niti upoštevali v končnem vrednotenju.

Osnovni: Spremljanje potovalnih navad

Dopolnilna: Delovanje prometnega oddelka na občini, oziroma za promet posebej zaposlenih oseb

Povezanost s sosednjimi občinami

Obrazložitev: Ta vidik sicer ni vključen v metodologijo vrednotenja, a je nanj pomembno opozoriti, saj je ustrezno načrtovanje prometa osnova kakovostnega sistema mobilnosti. Pomanjkljivost tega kazalca je, da večinoma nikjer ne spremljajo potovalnih navad, razen v nekaterih večjih občinah, pa tudi prometnega oddelka večinoma še nimajo, kar kaže na skromnost osnovnih pogojev za zagotavljanje kakovostnega javnega prometa.

\section{REZULTATI VREDNOTENJA OBČIN IN SKLEP}

Po pregledu ukrepov v izbranih občinah in njihovem ovrednotenju smo prišli do sledečih rezultatov:

Raznolikost ponudbe (število možnih točk 8): Ljubljana 8, Koper in Postojna po 7 točk Trend prevozov (število možnih točk 4): Koper, Novo mesto, Velenje in Postojna po 4 točke Cenovna politika (število možnih točk 4): Ljubljana, Velenje, Nova Gorica in Piran po 4 točke

Kakovost voznega parka (Število možnih točk 5,5): Piran 5,5, Krško 4,5, Velenje in Postojna po 3,5 točk

Opremljenost postajališč (število možnih točk 3): Ljubljana, Kranj, Novo mesto, Velenje, Nova Gorica in Krško po 3 točke

Intermodalnost (število možnih točk 5): Ljubljana 4, Koper, Krško in Jesenice po 3 točke Načrtovalski vidik (le informativna kategorija)

Seštevek točk (število možnih točk 29,5): Ljubljana 23,5;Velenje 20,5; Krško 19,5; Nova Gorica 19; Piran 18,5; Postojna 17,5

Povprečno število točk med izbranimi občinami: 12,2

Slika 2 nam pokaže, da so največ točk dosegli v Ljubljani $(23,5)$, kar pomeni 80-odstotno uspešnost. Nad 20 točk ima še mestna občina Velenje. Najšibkejši so sistemi javnega potniškega prometa pri doseganju intermodalnosti, kar je velik problem, saj ravno intermodalnost omogoča učinkovito delovanje sistemov javnega potniškega prometa, tako pri navezavi na individualni promet, kot med različnimi oblikami javnega potniškega prometa. Slika 2 tudi pokaže, da vrstni red ne sledi velikosti občin. Če izvzamemo Ljubljano, se izkaže, da so manjše občine, oziroma občine z mlajšim in manjšim sistemom javnega potniškega prometa, bolj prizadevne pri spremembah, saj se manjši sistemi hitreje odzivajo na spremembe kot veliki. Npr., menjava voznega parka v občini z deset ali manj vozili stane precej manj kot v večjih občinah s precej večjim voznim parkom, 
Slika 2: Razporeditev občin po izvajanju ukrepov na področju javnega potniškega prometa v letu 2011

Figure 2: Distribution of municipalities according to implementation of measures in public transport

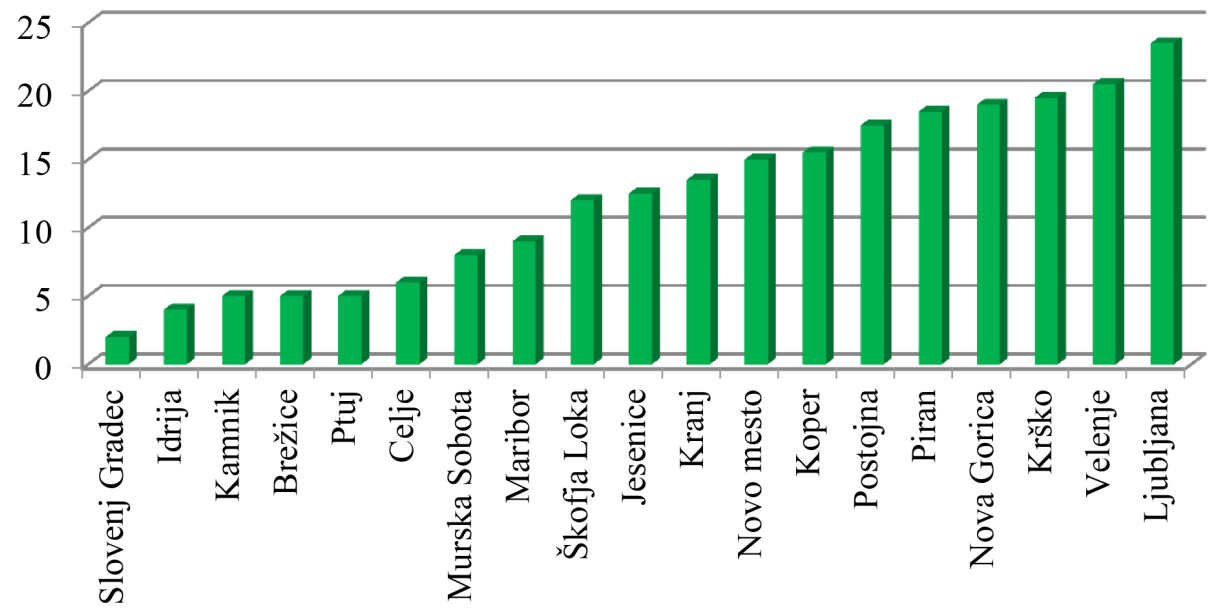

hkrati pa se zelo hitro poveča delež vozil z višjim emisijskim standardom. Po obstoječi metodologiji je v najslabšem položaju Ljubljana, saj je njen sistem javnega potniškega prometa daleč največji in prepelje kar 92 \% vseh potnikov, ki uporabljajo javni potniški promet v izbranih občinah. Na drugem mestu je Maribor s $4 \%$, preostanek (4\%) pa se porazdeli na ostalih 17 občin. Vseeno pa so jasne razlike med večjimi občinami, kjer je Ljubljana na vrhu, Celje in Maribor pa sta v spodnji polovici.

Analiza dodatnih ukrepov, ki niso všteti v vrednotenje, je pokazala, da Ljubljana resnično vlaga napore v razvoj javnega potniškega prometa, česar pa za Maribor in Celje ne moremo potrditi v enaki meri. Tudi med manjšimi občinami so opazne velike razlike, saj so nekatere v zadnjih letih začele vlagati v razvoj javnega potniškega prometa, npr. Piran, Nova Gorica, Velenje, druge pa še ne ali pa so o tem šele razmišljale (Kamnik). Samo en ukrep, npr. uvedba poceni ali celo zastonj avtobusne proge, nikakor ni dovolj, kar kaže primer občine Murska Sobota, ki se nahaja v spodnji polovici lestvice.

Pomemben kazalec pri vlaganju v sistem javnega potniškega prometa na ravni občine je tudi število zaposlenih na prometnem oddelku občine, oziroma ali ta oddelek sploh obstaja. Na ta način se kaže zavedanje vodilnih v občini, kako pomembno je urejanje mobilnosti. To je tudi prvi pogoj za celovit pristop k urejanju mobilnosti. Čeprav tega kazalca nismo točkovali in ni vplival na končno oceno, se je izkazalo, da občine večinoma nimajo takih oddelkov, niti se jim ne zdi potreben, oziroma o njem ne razmišljajo.

Izvedeno vrednotenje ni namenjeno tekmovanju med občinami, pač pa predvsem pregledu stanja vlaganj in nabora ukrepov, ki so jih občine izvedle v sistemu javnega potniškega prometa. Menimo, da je takšno vrednotenje koristno za primerjavo občin v večletnem obdobju. Z njim lahko spremljamo napredek občinskih prometnih politik na 
področju javnega potniškega prometa in tudi celotno stanje javnega potniškega prometa v slovenskih občinah. Tovrstno vrednotenje lahko prispeva tudi k pozitivni motivaciji občin in prenašanju pozitivnih ukrepov na druge. $Z$ leti se bo tudi pokazalo, kateri deli metodologije so potrebni dopolnitve. Ena od slabosti se je pokazala pri kazalcih o opremljenosti postajališč, saj zaposleni pogosto ne poznajo pravega stanja in so njihove ocene manj točne oziroma bolj subjektivne, kar zahteva več ponovnega preverjanja.

Slika 3: Vrednotenje javnega potniškega prometa po občinah

Figure 3: Evaluation of public transport by municipalities

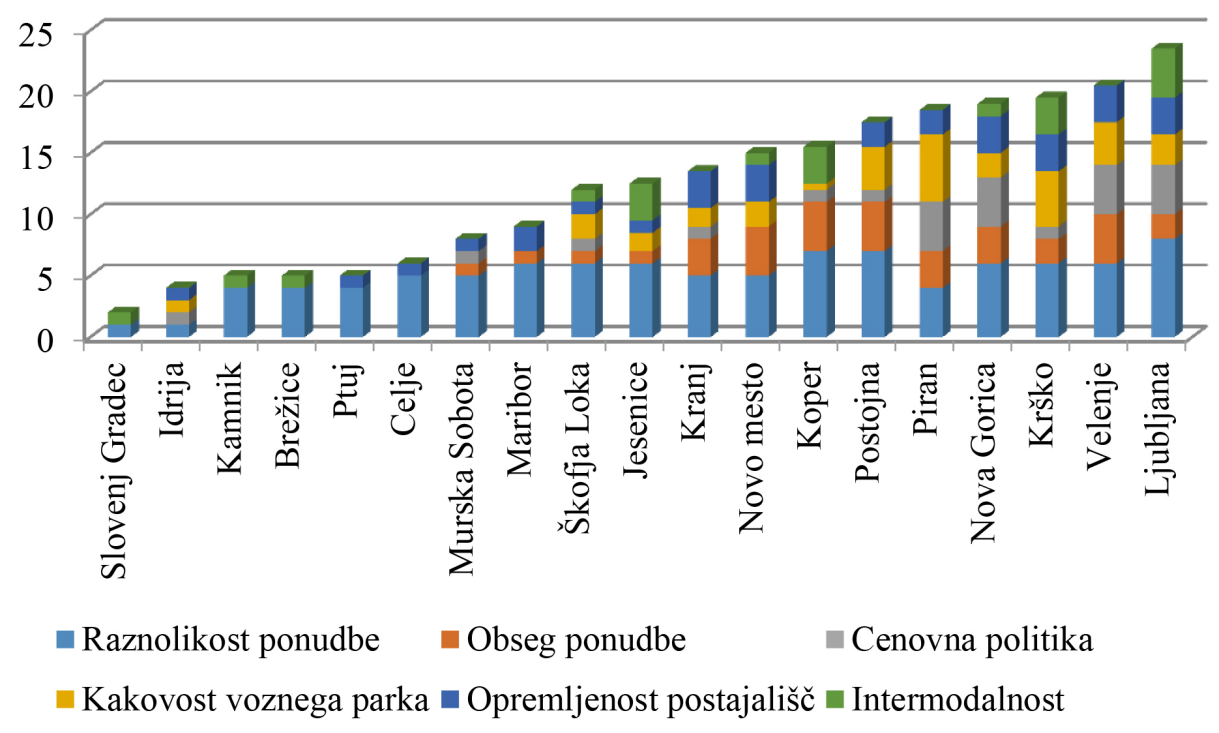

Raziskava je pokazala tudi, da marsikje sicer vse bolj odločno vlagajo v sisteme javnega potniškega prometa, a celostnega, sistemskega pristopa k razvoju javnega potniškega prometa še nimamo nikjer. Zgolj delna vlaganja $v$ sisteme javnega potniškega prometa sicer koristijo, a ne zadostujejo za temeljito prenovo sistema javnega potniškega prometa v Sloveniji. Veliko je odvisno tudi od države ter njene podpore in vlaganj v sisteme javnega potniškega prometa, saj so zlasti manjše občine kadrovsko in finančno prešibke za večja vlaganja. Izkazalo se je tudi, da marsikje sploh ni ustreznega znanja o sodobnih trendih na področju javnega potniškega prometa. Dogajanje po koncu raziskave kaže, da zelo verjetno vstopamo v bolj dinamično obdobje večjih sprememb na področju javnega potniškega prometa $\mathrm{v}$ Sloveniji, ki bodo stanje obrnile na bolje.

\section{Viri in literatura}

Bole, D., Gabrovec, M., 2012. Daily commuters in Slovenia. Geografski vestnik, 84, 1, str. 171-185. URL: http://zgs.zrc-sazu.si/Portals/8/Geografski_vestnik/vestnik84-1-bole-gabrovec.pdf (Citirano 16. 12. 2013). 
EU transport in figures: statistical pocketbook 2014. 2014. Luxembourg, Publications Office of the European Union, 148 str. URL: http://ec.europa.eu/transport/facts-fundings/statistics/doc/2014/pocketbook2014.pdf (Citirano 12. 11. 2014).

Greenhouse gas emission trends and projections in Europe 2012: tracking progress towards Kyoto and 2020 targets. 2012. København, European Environment Agency. URL: http://www.eea.europa.eu/publications/ghg-trends-and-projections-2012 (Citirano 16. 11. 2013).

Jemenšek, B., 2010. Model vzpostavitve konkurenčnega in trajnostnega javnega prevoza v občini Škofja Loka. V: Zbornik referatov: 10. slovenski kongres o cestah in prometu (Portorož, 20.-22. oktobra 2010). Ljubljana, DRC - Družba za raziskave v cestni in prometni stroki Slovenije, str. 279-288.

Jezeršek, D., 2012. Mesta in javni potniški promet: analiza stanja mestnega javnega potniškega prometa v Mestni občini Koper in Občini Piran. Annales, 22, 1, str. 277-292.

Kakovost zraka v Sloveniji v letu 2012. 2013. Ljubljana, ARSO, 141 str. URL: http:// www.arso.gov.si/zrak/kakovost\%20zraka/poro\%C4\%8Dila\%20in\%20publikacije/ KAKOVOST\%20ZRAKA\%202012.pdf (Citirano 5. 12. 2013).

Kozina, J., 2010. Transport accessibility to regional centres in Slovenia (Prometna dostopnost do regionalnih središč). Acta Geographica Slovenica, 50, 2, str. 231-251. DOI: 10.3986/AGS50203

Lampič, B., Ogrin, M., 2009. Razvoj in vloga cestnega prometa. V: Okoljski učinki prometa in turizma v Sloveniji (Zbirka GeograFF, 5). Ljubljana, Znanstvena založba Filozofske fakultete, str. 22-45. URL: http:/geo.ff.uni-lj.si/sites/default/files/geograff_5.pdf (Citirano 16. 11.2013).

Mekinda, T., Česen, M., 2012. Izpusti toplogrednih plinov iz prometa. Kazalci okolja v Sloveniji. 2012. Ljubljana, Agencija Republike Slovenije za okolje. URL: http:// kazalci.arso.gov.si/?data=indicator\&ind_id=619 (Citirano 18. 12. 2013).

Ogrin, D., Ogrin, M., Čemas, D., Planinšek̄, A., 2006. Prometno onesnaževanje ozračja v Ljubljani znotraj avtocestnega obroča. Končno poročilo raziskovalnega projekta. Ljubljana, Filozofska fakulteta, Oddelek za geografijo, 73 str.

Ogrin, M., Resnik Planinc, T., Ilc Klun, M., Plevnik, A., 2013. Trajnostna mobilnost: priročnik za učitelje v osnovnih šolah. Ljubljana, Ministrstvo za infrastrukturo in prostor, 93 str.

Ogrin, M., 2008. Prometno onesnaževanje ozračja z dušikovim dioksidom v Ljubljani (Zbirka GeograFF, 1). Ljubljana, Znanstvena založba Filozofske fakultete, Oddelek za geografijo, 87 str. URL: http:/geo.ff.uni-lj.si/sites/default/files/geograff_1.pdf(Citirano 18. 11. 2013).

Ogrin, M., Vintar Mally, K., 2013. Primerjava poletne onesnaženosti zraka z dušikovim dioksidom v Ljubljani med letoma 2005 in 2013. Dela, 40, str. 55-72. DOI: 10.4312/ dela.40.4.55-72

Ogrin, M., Vintar Mally, K., Planinšek, A., Močnik, G., Drinovec, L., Gregorič, A., Iskra I., 2014. Onesnaženost zraka v Ljubljani: koncentracije dušikovih oksidov, ozona, benzena in črnega ogljika v letih 2013 in 2014 (Zbirka GeograFF, 14). Ljubljana, Znanstvena založba Filozofske fakultete, 123 str. 
Rode, B., 2009. Izpusti dušikovih oksidov. Kazalci okolja v Sloveniji. URL: http://kazalci.arso.gov.si/?data=indicator\&ind_id=161 (Citirano 5. 11. 2013).

Sector share of nitrogen oxides emissions (EEA member countries). European Environment Agency. 2012. URL: http://www.eea.europa.eu/data-and-maps/figures/ sector-share-of-nitrogen-oxides-emissions-eea-member-countries-3 (Citirano 26. 11. 2013).

Zupančič, P., 2007. Javni potniški promet na ruralnih območjih Republike Slovenije v funkciji zadovoljevanja javnih potreb. Magistrska naloga. Ljubljana, Fakulteta za gradbeništvo in geodezijo, 189 str. URL: http://drugg.fgg.uni-lj.si/2083/1/ GRM_0194_Zupancic.pdf(Citirano 18.11.2013).

\section{EVALUATION OF PUBLICTRANSPORT IN SELECTED SLOVENIAN MUNICIPALITIES}

\section{Summary}

Public transport in developed countries is an important alternative to private vehicle transport (i.e. automotive), significantly contributes to social equality in mobility and integrates all social groups into social circles. Also, developed public transport significantly reduces congestion on urban roads, increases energy and cost efficiency of the transport system, contributes to greater traffic safety and reduces air pollution, environmental noise pollution and greenhouse gas emissions.

In the last 30 years, Slovenia has gone through some major changes in the field of public transport. Unfortunately, many of these changes turned the situation for the worse, which can be confirmed by many indicators. The rapid growth of motorisation has revolutionised our way of life and has enabled faster and more diverse mobility. At the same time, it has brought about many negative changes. Nowadays, Slovenia is among the most motorised nations in Europe. With $86 \%$ of terrestrial journeys carried out by car, Slovenia is ranked third in the EU (EU transport in figures 2014, 2014).

In order to get a more detailed and comprehensive insight into the state of public transport, we started a research on measures in public transport in particular municipalities in Slovenia where such transport is organised. The research also showed the situation in certain segments of public transport in selected municipalities as well as certain problems in the methodology itself that need to be eliminated in the following years when this type of research is repeated.

We found that the weakest point in public transport systems is the achieving of intermodality. This proves to be a great problem, as it is precisely intermodality that enables efficient operation of public transport systems, both in connection to individual types of traffic and among different forms of public transport. The research shows that the order is not dependent on the size of municipalities. Aside from Ljubljana, it turns out that the smaller a municipality is, or the younger and smaller its public transport system, the more successful it is in implementing changes, as smaller systems respond to changes more quickly than larger ones. Considering the current methodology, Ljubljana, with by far the 
largest public transport system, is in the worst situation, transporting $92 \%$ of all publictransport-using passengers within the selected municipalities. However, there are clear differences among major municipalities, with Ljubljana at the top and Celje and Maribor in the lower half.

An analysis of additional measures not included in the evaluation showed that Ljubljana indeed puts a lot of effort into the development of public transport, which cannot be confirmed for Maribor and Celje, at least not to the same extent. One can notice significant changes among smaller municipalities as well, as in recent years some of them already began to invest in public transport development (e.g. Piran, Nova Gorica, Velenje), while others have not or are still in the phase of considering these issues. As shown in the example of Murska Sobota in the lower half of our scale, one sole measure (e.g. the introduction of cheap or even free bus routes) is clearly insufficient.

(Translated by Prevajalska agencija Julija) 